\title{
THE GLORY OF DEATH? GERMAN MEMORIALS OF THE GREAT WAR IN THE NORTH-WESTERN CZECH BORDERLANDS AFTER 1945
}

\author{
KAROLINA ĆWIEK-ROGALSKA
}

INSTITUTE OF SLAVIC STUDIES, POLISH ACADEMY OF SCIENCES

\begin{abstract}
War memorials (in German, Kriegerdenkmäler) were built after World War I in almost every village and town in Czechoslovakia that had a German population, to commemorate those who had been killed in the war. After 1945, these memorials were either destroyed or recycled. The author shows how the new Czech inhabitants who replaced the traditional population of the borderlands coped with these memorials. Focusing her research on the Cheb and Mariánské Lázně regions, she considers the destruction of the monuments to be an example of managing a "dissonant heritage." Some of the monuments were demolished altogether; others were re-used for new purposes as parts of new objects. Applying Reinhart Koselleck's theory that war memorials serve the living more than they do the dead, by creating communal attitudes toward common social issues, the author analyzes patterns in the erection of German memorials of the Great War in the Czech lands. She also refers to Bernhard Böttcher's analysis of German war memorials in Czechoslovakia, which regards them as monuments commemorating a country which had ceased to exist. Her main thesis is that the "new life" given to war memorials after 1945 is connected to a new and different perspective among Czechs on World War I, to their hostile attitude towards the German heritage of Czechoslovakia, and to a different perception of memorials inherited from the past.

Keywords: World War I; war memorials; dissonant heritage; Czechoslovakia; German minority DOI: $10.14712 / 23363231.2019 .10$

The article is an extended version of a presentation given at the workshop "Grenze/n, Gedächtnis, Friedhöfe" held in Prague on September 26 and 27, 2018 and organized by the research consortium Grenzen in Erinnerungskulturen.

Karolina Ćwiek-Rogalska, PhD, is an assistant professor at the Institute of Slavic Studies, Polish Academy of Sciences in Warsaw. Address correspondence to Instytut Slawistyki PAN, ul. Bartoszewicza 1b/17, 00-337 Warszawa, Poland. E-mail: karolina.rogalska@ispan.waw.pl.
\end{abstract}




\section{Introduction}

Great War memorials are common features of the cultural landscape of all countries that took part in World War I. Starting with the countries that were among the main participants of that war, we note the British war memorials ${ }^{1}$ and French monuments aux morts ${ }^{2}$ on the side of the Entente, and from the other side of the conflict, the German Kriegerdenkmäler. ${ }^{3}$ The "orgy of monumentalization," as the postwar wave of erecting Great War memorials has been called by memory studies scholar Paul Connerton, ${ }^{4}$ was a large-scale phenomenon not only in Europe, but also in the United States, which had in 1917 declared war on Germany and become an active participant in the conflict. ${ }^{5}$ The situation of the Central European states that emerged from the war as independent countries was slightly different, as was their remembrance of that conflict. The collective memory, ${ }^{6}$ as well as the common perception of the outcome of the war was not the same as in Western Europe and America. The way the societies of the newly founded states, including Czechoslovakia and Poland, perceived the Great War was atypical in comparison with the Western perspective. ${ }^{7}$

That does not mean there were no war memorials in those countries, but the communities that erected them, their reasons for building them, and the

1 Jonathan A. Black, "Ordeal and Reaffirmation: Masculinity and the Construction of Scottish and English National Identity in Great War Memorial Sculpture 1919-30," in Memory and Memorials: The Commemorative Century, ed. William Kidd and Brian Murdoch (London: Routledge, 2017), 75-91; Stefan Goebel, The Great War and Medieval Memory: War, Remembrance and Medievalism in Britain and Germany, 1914-1940 (Cambridge: Cambridge University Press, 2007); George L. Mosse, Fallen Soldiers: Reshaping the Memory of the World Wars (New York: Oxford University Press, 1991).

2 Annette Becker, La guerre et la foi. De la mort à la mémoire: 1914-années 1930 (Paris: Armand Colin, 2015).

3 Goebel, The Great War and Medieval Memory; Reinhart Koselleck, "War Memorials: Identity Formations of the Survivors," in The Practice of Conceptual History: Timing History, Spacing Concepts, ed. Reinhart Koselleck and Todd Samuel Presner (Stanford, CA: Stanford University Press, 2002), 285-326; Reinhart Koselleck and Michael Jeismann, eds., Der Politische Totenkult: Kriegerdenkmäler in der Moderne (Paderborn: Wilhelm Fink, 1994); Mosse, Fallen Soldiers.

4 Paul Connerton, “Seven Types of Forgetting," Memory Studies 1, No. 1 (January 2008): 69, doi: $10.1177 / 1750698007083889$.

5 Steven Trout, On the Battlefield of Memory: The First World War and American Remembrance, 1919-1941 (Tuscaloosa, AL: University of Alabama Press, 2010); Jennifer Wingate, Sculpting Doughboys: Memory, Gender, and Taste in America's World War I Memorials (London: Routledge, 2017).

6 Jeffrey K. Olick, “Collective Memory: The Two Cultures," Sociological Theory 17, No. 3 (November 1999): 333-348, doi: 10.1111/0735-2751.00083.

7 Maciej Maria Górny, "All Quiet? The Memory and Historiography of the First World War in Poland,” Rúbrica Contemporánea 3, No. 6 (2014): 37-46. 
states' official strategies for coping with their erection and their results differed from the West. In Czechoslovakia, we can distinguish war memorials built by the Czech majority ${ }^{8}$ from memorials erected by the German minority. ${ }^{9}$ The latter memorials are especially interesting from the point of view of the anthropological inquiry that I undertake in this paper. The aim of my article is to analyze the war memorials built by the German-speaking communities in Czechoslovakia in the inter-war period, which were subjected to cultural recycling after 1945 after those communities had been expelled from the country. I will address such research questions as: what kind of heritage are we dealing with when we discuss the memorials erected by the German-speaking population of Czechoslovakia between 1918 and 1938? Is the common belief true, that after 1945 all that was perceived as "German" was destroyed or left to be devoured by time? If so, did the region's new inhabitants differentiate between the different war memorials that they came across in their new homeland? What types of German Great War memorials can be seen in the Czech borderlands? Were there any reasons why some of them were re-used or preserved and others were destroyed?

After 1945, the so-called Czech borderlands (in Czech, pohraniči), ${ }^{10}$ as well as other parts of the Czech lands, such as isolated language islands, ethnic neighborhoods of larger cities, and other areas that were inhabited mostly by German-speaking inhabitants, were subjected to forced migration of German- and Czech-speakers and speakers of other languages. ${ }^{11}$ So-called "wild expulsions" of German-speaking inhabitants took place before the Allies' Potsdam conference in July 1945, while other, organized expulsions occurred later on. The forced migration of Czech-speakers and speakers of some other non-German

8 See Zdeněk Hojda and Jiří Pokorný, Pomniky a zapomníky (Praha: Paseka, 1997), 164-174; Martin Zückert, Zwischen Nationsidee und staatlicher Realität. Die tschechoslowakische Armee und ihre Nationalitätenpolitik 1918-1938 (München: Oldenbourg, 2006), 217-221; Marcin Jarząbek, Legioniści i inni: Pamięć zbiorowa weteranów I wojny światowej w Polsce i Czechosłowacji okresu międzywojennego (Kraków: Towarzystwo Autorów i Wydawców Prac Naukowych 'Universitas', 2017), 181-184; Jan Galandauer, "Hrob neznámého vojína v proměnách času," Historie a vojenství 48, No. 2 (1999): 251-273.

9 See Bernhard Böttcher, Gefallen für Volk und Heimat: Kriegerdenkmäler deutscher Minderheiten in Ostmitteleuropa während der Zwischenkriegszeit (Köln: Böhlau, 2009).

${ }^{10}$ Matěj Spurný, Nejsou jako my: česká společnost a menšiny v pohraničí (1945-1960) (Praha: Antikomplex, 2011), 25-26; Andreas Wiedemann, "Pojd's námi budovat pohraničí!" Osídlování a proměna obyvatelstva bývalých Sudet 1945-1952 (Praha: Prostor, 2016), 27; Jan Jeništa, "Pogranicze w Czeskiej Perspektywie Oglądu," in Pograniczność i pogranicza w perspektywie nauk społecznych i humanistycznych, ed. Wojciech Chlebda and Ivana Dobrotová (Opole: Wydawnictwo Uniwersytetu Opolskiego, 2015), 19-28.

${ }_{11}$ Adrian von Arburg, Tomáš Dvořák, and David Kovařík, Německy mluvící obyvatelstvo v Československu po roce 1945 (Brno: Matice moravská, 2010). 
languages took place after the "Victorious February" of 1948 and the communist takeover of power in Czechoslovakia. These radical demographic changes had an immense influence on the culture of the border regions. The war memorials built by the German-speaking minority were destroyed, neglected or re-used for new purposes after these communities were expelled and the regions were resettled. Following the demographic changes, the regions adopted a cultural landscape belonging to a different, homogeneously "Czech and Slovak" society with a different historical memory than that shared by the German-speaking communities that had built the memorials years earlier.

I propose to analyze a particular region of the borderlands: the commune of Dolní Žandov and its neighborhood. For the purposes of this paper, I will refer to them as the regions of Chebsko (Egerland) and Mariánskolázeňsko (Marienbad Region). The regions are interesting for purposes of this paper for several reasons, but among other things, they showcase the processes that took place more generally in the borderlands. However, one should bear in mind that it is not all that simple to draw conclusions about the borderlands as a whole because of the diversity of its regions. Similar processes took place everywhere (demographical changes, the establishment of forbidden zones, demolitions), but they could look different when it came to details. I chose Dolní Žandov because no anthropological research had as yet been done there. ${ }^{12}$ The region is a kind of historical "blank space" on the map of the Czech borderlands. Moreover, typical kinds of German war memorials can be found there, and it is possible to analyze them with reference to local conditions. Although there is a published catalog of German war memorials in the two regions, ${ }^{13}$ it focuses mostly on documenting the memorials without analyzing them. I will use visual and oral material gathered during my fieldwork for deeper analysis.

\section{Methodological Remarks}

This paper is interdisciplinary in character. It depends on anthropological fieldwork, combining methods from such disciplines as history, memory, culture

12 There have been two minor ethnographic research projects conducted by the Cheb Museum. In 1983 , one documented the condition of the villages in photography, and in 2001, the museum conducted a pilot study in the region, during which some older inhabitants were asked for their recollections of the past, which were recorded. No analysis of the materials gathered was published, however.

13 Zbyněk Černý and Tomáš Dostál, Bolest v kameni. Pomníky vojákưm z chebských jednotek padlým v první světové válce (Cheb: Krajské muzeum Karlovarského kraje, 2007). 
and landscape studies. The basic material to be analyzed was gathered during extensive fieldwork in the commune of Dolní Žandov, starting in 2012 and ending in 2014. ${ }^{14}$ My fieldwork was aimed mainly at the inhabitants' perception of their cultural landscape and its elements, one of which is the German monuments in the region. ${ }^{15}$

According to the founding father of the school of the interpretative anthropology, Clifford Geertz, ethnography should not make general assumptions based on fieldwork done in one village, although it is possible to derive great ideas based on the analysis of one minor phenomenon. ${ }^{16}$ Sharing that Geertzian belief, I base my analysis of the German war memorials in the Czech borderlands on fieldwork I have done in one small village community in the north-western part of the contemporary Czech Republic. As an anthropologist, I use fieldwork as my main tool for gathering materials, consisting of participant observation as well as interviews.

During my fieldwork I conducted 35 interviews with the inhabitants of the Dolní Žandov area. I interviewed Czechs and Slovaks who were among the new settlers who moved there after 1945, a Czech-German family that was expelled in the so-called "internal expulsion" (in Czech, vnitřni odsun) in the late 1940s, and one German family that emigrated later, in the 1950s, to West Germany. I also transcribed and used four interviews that were gathered during pilot research done by the Cheb Museum in 2001. Those interviews were taped and are stored in the sound recordings library in the Cheb Museum but they have never been transcribed or analyzed before. ${ }^{17} \mathrm{My}$ typical interviewee was more than 80 years old and moved to Žandov in the second half of the 1940s, so s/he briefly experienced the presence of German-speaking inhabitants of the village until they were displaced.

\section{War Memorials and Their Meaning}

To start my examination, I should first address the question, what exactly can be defined as a war memorial? The "orgy of monumentalization" that swept through Europe after 1918, as it is referred to by Connerton, reflected

${ }^{14}$ Detailed information about the fieldwork can be found in Karolina Ćwiek-Rogalska, Zapamiętane w krajobrazie. Krajobraz czesko-niemieckiego pogranicza w czasach przemian (Warszawa: Wydawnictwo Naukowe Scholar, 2017), 19-28.

15 See Ćwiek-Rogalska, Zapamiętane w krajobrazie.

16 "Thick Description: Toward an Interpretive Theory of Culture," in Clifford Geertz, The Interpretation of Cultures. Selected Essays (New York: Basic Books, 1973), 3-30.

17 “Dolní Žandov - pamětníci," file 53, sound recordings library, Cheb Museum. 
the massive number of the war's victims, soldiers as well as civilians, who were killed between 1914 and 1918. In some regions they died even later, especially where the local wars that established the frontiers of the newly founded states were fought. The victims of these later conflicts are often included in the list of deceased and fallen in the Great War. ${ }^{18}$ In this paper, I understand "Great War memorials" as memorials of different kinds that commemorate soldiers who fell between 1914 and 1918, which were erected in the places from which the fallen came. They do not commemorate a particular event of the war, but rather particular groups of soldiers: those who served in the same regiment, came from the same place, or belonged to the same parish. They commemorate one event (the Great War), but are divided into local parts, so that they can be referred to as a kind of "scattered monument" (in Czech, rozptýlenýpomnik). ${ }^{19}$ In this paper I do not analyze any one "central" memorial devoted to all Czech or German soldiers or one that commemorates a particular battle.

At least three reasons for erecting Great War memorials can be distinguished: (1) the desire to make some sense of an unbelievably savage war, the likes of which had never been experienced before, ${ }^{20}$ (2) the wish to mourn the victims, who had been deprived of their individuality by the massive death toll of the war, ${ }^{21}$ in a more individual way than did the tomb of an unknown soldier that was erected in the capital of almost every state after 1918, ${ }^{22}$ and (3) the need to redefine the notion of the "nation," which changed in the course of postwar events such as the break-up of prewar multinational states like Austria-Hungary. ${ }^{23}$

Several approaches to dealing with war memorials can be identified. For a long time, they were seen as objects that propagated the ideas that triggered the

${ }^{18}$ In the case of the Czech borderlands, the cult of those German citizens who were killed on March 4, 1919 in the bloody repression of demonstrations demanding the inclusion of the Sudetenland in Austria is especially interesting. See Böttcher, Gefallen für Volk und Heimat, 174-176.

19 This term was proposed by Vojtěch Kessler in his work on Czech war memorials. See Vojtěch Kessler, Pamět'v kameni. Druhý život válečných pomníků (Praha: Historický ústav AV ČR, 2017), 12.

${ }^{20}$ Laurence van Ypersèle, "Making the Great War Great: 1914-18 War Memorials in Wallonia," in Memory and Memorials. The Commemorative Century, ed. William Kidd and Brian Murdoch (London: Routledge, 2017), 26; Zückert, Zwischen Nationsidee und staatlicher Realität, 212.

${ }^{21}$ Jay Winter, Sites of Memory, Sites of Mourning: The Great War in European Cultural History (Cambridge: Cambridge University Press, 1998).

22 Vojtěch Kessler, Pamět v kameni, 35; Galandauer, "Hrob neznámého vojína," 251-273; Laura Wittman, The Tomb of the Unknown Soldier, Modern Mourning, and the Reinvention of the Mystical Body (Toronto: University of Toronto Press, 2011).

${ }^{23}$ Böttcher, Gefallen für Volk und Heimat, 1. 
next "great war," especially in the German case. Because they were used by Nazi propaganda as political tools, academics analyzed them mainly in terms of politics, overlooking other possible perspectives on war memorials. Commenting on classic works on war memorials by George L. Mosse, ${ }^{24}$ Reinhart Koselleck, and Michael Jeismann, ${ }^{25}$ as well as newer works by Jay Winter and Emmanuel Sivan, ${ }^{26}$ Stefan Goebel argues that war memorials have more than one side that should be taken into consideration. They not only reflected the deep trauma that the war was for Europeans, a trauma "understood as a sustained mass experience leaving particularly dense memory traces," 27 but they could also be considered as compensation for the lack of any graves for the dead bodies of soldiers who were not brought home, especially in the case of Great Britain and Germany. ${ }^{28}$ Moreover, analysis of war memorials links the private (families' bereavement) with the public (monumentalized manifestations). Mourning was personal, but its manifestation in form of commemorative monuments was a social practice that involved social networks and a new language of commemoration that was created on the public level. ${ }^{29}$ As work by Goebel proves, it is not the difference between victory and defeat that is crucial when analyzing war memorials, but the balance between the individual and group practices that were created around the monuments. This is further borne out by Goebel's comparative analysis of British and German Great War memorials. In my research and analysis, I find it inspiring to use his observations to analyze the (victorious) Czech memorials and the (defeated) German war memorials. I will also call upon his observations about the medieval motifs of Great War commemorative monuments, which can also be found in Czech and German monuments to the fallen.

Similar observations have been made by a German art and culture historian, Michaela Stoffels. Stoffels argues that it is impossible to separate all the meanings carried by the Great War memorials. ${ }^{30}$ We should remember that in addition to the top-down meanings, later re-used by Nazi propaganda, there were also bottom-up meanings that were important to local inhabitants. The monuments commemorated the local dead and served to channel their families'

${ }^{24}$ Mosse, Fallen Soldiers.

${ }^{25}$ Koselleck and Jeismann, eds., Der Politische Totenkult.

${ }^{26}$ Jay Winter and Emmanuel Sivan, eds., War and Remembrance in the Twentieth Century (Cambridge: Cambridge University Press, 2000), doi: 10.1017/CBO9780511599644.

27 Goebel, The Great War and Medieval Memory, 2-3.

${ }^{28}$ Ibid., 3.

${ }^{29}$ Ibid., 5.

${ }^{30}$ Michaela Stoffels, Kriegerdenkmale als Kulturobjekte: Trauer- und Nationskonzepte in Monumenten der Weimarer Republik (Wien: Böhlau, 2011). 
bereavement. They were not usually administered by central, state-controlled entities, but were designed, erected and maintained by local communities. They included nationally oriented expressions of meaning. The repertoire of visual and symbolic means was, as Koselleck notes, not very wide. ${ }^{31}$ They included local expressions of meaning, most prominently the list of names of the fallen from the local community. The memorials can and should be analyzed as Kulturobjekte $^{32}$ and not only as political statements or tools.

In analyzing the Czech and Czech-German memorials, as distinct from the British and German memorials compared by Goebel, it is important to remember that we are dealing with memorials erected in one country by members of the national majority and a national minority. The term "minority" in the case of Czech Germans can be misleading. ${ }^{33}$ I use it not to describe the absolute number of Czechoslovak citizens of German nationality, but their social status in the First Czechoslovak Republic. ${ }^{34}$ War memorials were erected not only by Germans in Germany and Austria. They were also erected by groups that identified with those nations or - generally speaking - with their culture, but who after the War lived in another state, one that was on the side of the victors. The fact that some Czech war memorials were dedicated to Czech soldiers who fought with the defeated armies constitutes another phenomenon worthy of further study.

Bernhard Böttcher, in his work devoted to Baltic, Czechoslovak and Romanian German minorities' memorials erected in the inter-war period, proposes yet another analytical perspective for dealing with the German minority's memorials in Czechoslovakia. He argues that it is possible to look at them not only as commemorations of particular fallen soldiers, but of the bigger entity that succumbed to the effects of the Great War: the state that ceased to exist. ${ }^{35}$ In this way the meaning behind the mourning that is inscribed on the German war memorials in the Czech lands is broader; it is a wake for the late Austro-Hungarian

${ }^{31}$ Koselleck, "War Memorials," 301.

32 Stoffels, Kriegerdenkmale als Kulturobjekte.

33 There were more Czech Germans in the First Czechoslovak Republic than there were Slovaks, and they were a majority in many of the regions where they lived, but Germans were a minority in the sense that the Czechs and Slovaks were the nations that shaped the new state and were represented by the name Czechoslovak Republic. See Adrian von Arburg and Tomáš Staněk, eds., Vysídlení Němců a promény českého pohraničí 1945-1951: Dokumenty z českých archivů, Part I (Středokluky: Zdeněk Susa, 2010), 80.

${ }^{34}$ Eagle Glassheim, "National Mythologies and Ethnic Cleansing: The Expulsion of Czechoslovak Germans in 1945," Central European History 33, No. 4 (December 2000): 467-468, doi: 10.1163/156916100746428.

35 Böttcher, Gefallen für Volk und Heimat, 1. 
Empire. Symbolically, the celebrations connected to these German memorials were conducted at the beginning of November, during the Roman Catholic feast days devoted to All Saints and, moreover, to all dead Catholics. There were no signs of "competitiveness" between the former Austrian citizens, Czech and German, in their commemorations. ${ }^{36}$ Böttcher stresses that there was no one community of "Czech Germans" because their culture was different depending on the region of Czechoslovakia in which they lived. ${ }^{37}$

The function of the German Great War memorials in the Czech lands changed after 1945 . They were no longer objects that consoled local communities, because the German-speaking communities ceased to exist with the forced migrations that started in 1945. New inhabitants, coming from all over the Republic, as well as from abroad, ${ }^{38}$ did not have any specific emotional attachment to the memorials in their locality. They knew only that they were connected with the former German presence in Czechoslovakia as such. The war memorials became part of a "dissonant heritage" as two British scholars, Gregory J. Ashworth and John E. Tunbridge, call the sum of the cultural artifacts in postconflict sites..$^{39}$ What is dissonant heritage? In music, when some chords are not played in a proper way, it creates a dissonant sound. When a heritage is not perceived as the things produced by "our" ancestors, but as the product of a different culture, which may in addition be hostile to "our own," it makes that heritage "dissonant." It does not harmonize with the dominant cultural landscape but creates dissonance as it is perceived by the new group that "inherits" the artifacts. It also recognizes that an inherited object can have different meanings while still having the same form. New groups can inscribe their own meanings onto the inherited form. This can be observed in the case of the Czech German war memorials. They are a "dissonant heritage" in two ways: they testify to "the dark side of the humanity" (war) ${ }^{40}$ but also to what happens as a result of radical socio-political change (in this case, the expulsion of almost entire minority population). The question of whether they are as well a destination for "dark tourism" merits further discussion.

36 Ibid., 176-178.

37 Ibid., 159, 164-165.

38 Spurný, Nejsou jako my, 115-133.

39 John E. Tunbridge and Gregory John Ashworth, Dissonant Heritage: The Management of the Past as a Resource in Conflict (New York: John Wiley \& Sons, 1996).

40 The author gives an overview of the theories concerning such heritage. See Joy Sather-Wagstaff, "Heritage and Memory," in The Palgrave Handbook of Contemporary Heritage Research, ed. Emma Waterton and Steve Watson (Basingstoke: Palgrave Macmillan, 2015), 195. 


\section{Czech and German War Memorials}

War memorials in the Czech lands are not only found in the borderlands. They were erected in almost all towns and villages to commemorate their citizens who fell in the Great War. They served not only as war memorials, but some also commemorated the establishment of an independent Czechoslovakia in that they were built to commemorate not only Czechs who served in the Austro-Hungarian army, but also the Czech and Slovak Legionnaires, whose story is intimately connected to the founding of the Republic. ${ }^{41}$ The war memorials are the litmus paper of an emerging national consciousness because their observers' reactions reflected their connection to the newly founded state. ${ }^{42}$ They can also be seen as a unifying force on the local level. As Koselleck argues,

memorials which commemorate violent death provide a means of identification. First, the deceased ... are identified in a particular respect: as heroes, victims, martyrs, victors, kin, possibly also as the defeated; in addition, as custodians or possessors of honor, faith, glory, loyalty, duty; and finally, as guardians and protectors of the fatherland, of humanity, of justice, of freedom.... Secondly, the surviving observers are themselves put in a position where they are offered an identity.... Their [fallen] cause is also ours. The war memorial does not only commemorate the dead; it also compensates for lost lives so as to render survival meaningful. Finally, there is the case contained in all the ones mentioned but which, taken in and of itself, means both more and less: that the dead are remembered - as dead. ${ }^{43}$

It should be repeated that the war memorials had meaning not only as commemorations of the Great War, but also as commemorations of the local dead. Of all the characteristics noted by Koselleck, "guardians and protectors" of the local community is most important in regard to the fallen soldiers who came from a particular town or village.

Both the Czech and the German war memorials demonstrate this meaning. However, we have to bear in mind that two separate canons were created in the historiography of the fallen. Although all the soldiers were fighting in the same war, and in most cases, in the same army, two different canons of

${ }^{41}$ Martin Zückert distinguishes between war memorials to fallen soldiers (Gefallenendenkmäler) and memorials devoted solely to fallen legionnaires (Legionärdenkmäler). See Zückert, Zwischen Nationsidee und staatlicher Realität, 220.

42 Kessler, Pamét'v kameni, 35.

43 Koselleck, "War Memorials," 287. 
commemoration arose, separating those who were commemorated. This happened in three different ways. Firstly, World War I could be perceived as a war that resulted in the creation of independent, more or less nationality-based states or it could be seen as a catastrophe that ended the old world where social and political rules were clear and "timeless." Secondly, the new state of Czechoslovakia had its own war heroes who were officially commemorated: the members of the Czechoslovak Legions. ${ }^{44}$ The legionnaires stood in opposition to the German dead. In some cases - a matter that needs further study - their status also differed from that of Czechs who fell in the service of other armies. Thirdly, the way memorials were "used" and the dates on which commemorations were organized around them were different. The main Czechoslovak commemorations took place on October 28, while Germans commemorated their losses a few days later, in early November. The former celebrations took on patriotic forms and meaning, while the latter were more connected to local sorrow and with religious forms and meaning. ${ }^{45}$

\section{Heroes' Groves}

I want to distinguish three different types of war memorials that are found in the regions under discussion. That does not mean that there are no other types of memorial there, but I find these three kinds to be the most interesting, especially when it comes to what happened to them after 1945. The first type is the so-called "heroes' grove" (in German, Heldenhain). The concept was first implemented by a German architect, Willy Lange, during the war. Lange proposed commemorating the dead symbolically: a tree was planted for each soldier individually, typically an oak, with its rich symbolic meaning in Teutonic folklore. With the addition of a memorial plaque for each fallen soldier, the grove took on the air of a cemetery. ${ }^{46}$ It is a particularly German way of honoring the dead that connects

${ }^{44}$ See Jarząbek, Legioniści i inni, 176-184; Zückert, Zwischen Nationsidee und staatlicher Realität, 214-216.

45 Böttcher, Gefallen für Volk und Heimat, 173-176.

46 Joachim Wolschke-Bulmahn, "Gärten, Natur und völkische Ideologie," in Die Ordnung der Natur: Vorträge zu historischen Gärten und Parks in Schleswig-Holstein, ed. Reiner Hering (Hamburg: Hamburg University Press, Verlag der Staats- und Universitätsbibliothek Hamburg, 2009), 143-187; Joachim Wolschke-Bulmahn and Gert Groening, "The Ideology of the Nature Garden. Nationalistic Trends in Garden Design in Germany during the Early Twentieth Century," The Journal of Garden History 12, No. 1 (1992): 73-80, doi: 10.1080/01445170.1992.10410571. 
nature and terrain with iconography. ${ }^{47}$ The oak was a metaphor that symbolized the traits of a good soldier in its solitary yet powerful nature. The stones used for memorial plaques were not without meaning either. Boulders, usually of granite, were considered to be truly "Germanic" in that they symbolized "primeval power" and "national" values deeply rooted in the past. ${ }^{48}$ In other cases, orphanlike, stand-alone memorial stones containing a plaque with the names of fallen soldiers were a popular way of commemorating the fallen. They fulfilled a desire that the local dead should be commemorated using local materials.

The Heldenhaine were modified after the war. For example, the linden that stood at the center of each heroes' grove, intended by Lange as a symbol of the emperor, was removed as the Republic replaced the monarchy..$^{49}$ In the regions of Chebsko and Mariánskolázeňsko there are two heroes' groves. The larger one is in Mariánské Lázně (see Image 1). There is a smaller one in the village of Horní Žandov (see Image 2). The new inhabitants who replaced the German speaking community of the region treated the groves as they did cemeteries, and frequently did not realize that they were only symbolic. As one of my interviewees stated,

And in fact, we're doing a cemetery now ... Or the cemetery, it's actually ... Everybody thought it was a cemetery, but it's actually a sacred place from the First World War. It's in Horní Žandov, and it's a commemoration of the victims of the First World War, right? Of those fallen in former Yugoslavia or so, and so they were doing memorials devoted to them like the one in Horní Žandov. It has appeared now, we are renovating it, so it will be theoretically done this year. ${ }^{50}$

Although this interviewee started talking about a "cemetery," he quickly switched to describing it as a "sacred place," with the emphasis on its connection to World War I. Furthermore, it is worth noting that he not only identifies

47 Sarah Elaine Lavallee, "Monumental Shifts in Memory: The Evolution of German War Memorials from the Great War to the End of the Cold War" (Doctoral Dissertation, Wichita State University, 2014), 14.

${ }^{48}$ Lavallee, "Monumental Shifts in Memory," 14; Karen E. Till, "Staging the Past: Landscape Designs, Cultural Identity and Erinnerungspolitik at Berlin's Neue Wache," Ecumene. A Journal of Cultural Geographies 6, No. 3 (July 1999): 257-258; Mosse, Fallen Soldiers, 88-89.

49 Mosse, Fallen Soldiers, 88.

50 Field interview, Dolní Žandov, taken on July 12, 2014. In the original Czech: „A vlastně ted'ka doděláváme hřbitov... Nebo hřbitov, ono to je vlastně... Všichni mysleli, že je to hřbitov, ale nakonec to je pietní místo z první světový války. To je v Horním Žandově, a to je na památku obětem 1. světové války, jo? Co padli třeba v bejvalé Jugoslávii nebo takhle, a tak se jim dělaly pomníčky jako třeba v Horním Žandově. Ten se ted'ka objevil, dává se dohromady postupně, takže ten bude teoreticky letos hotovej, zprrístupněnej." 


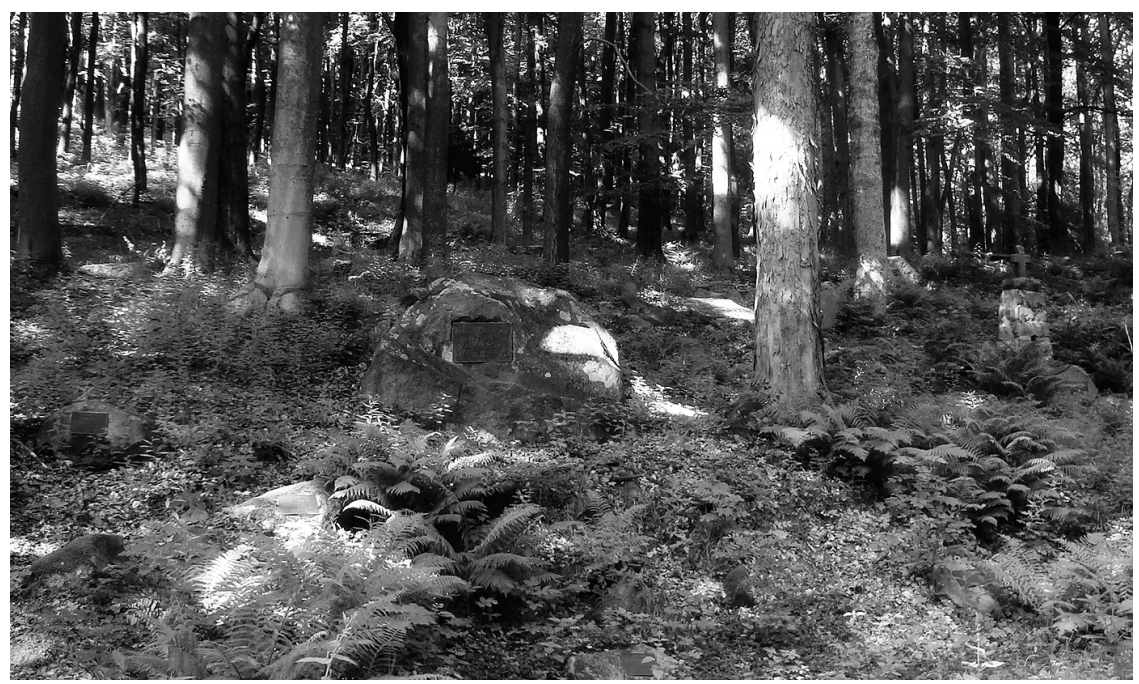

Image 1: Heroes' grove, Mariánské Lázně

Author: Karolina Ćwiek-Rogalska, 2013

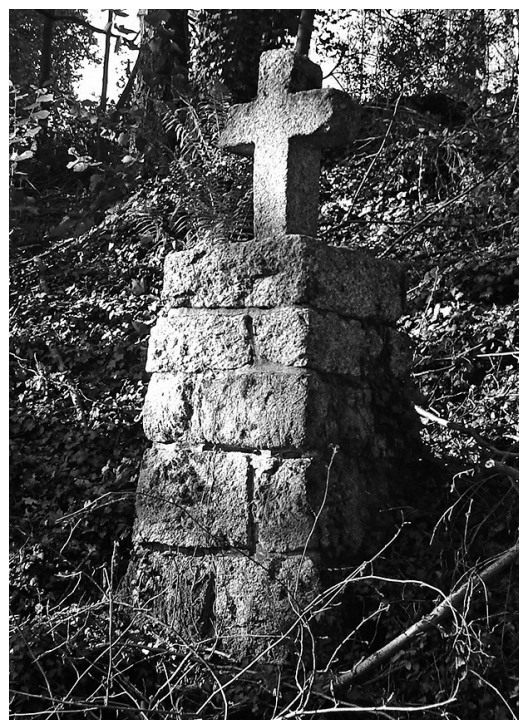

Image 2: A center piece in heroes' grove, Horní Žandov

Author: Karolina Ćwiek-Rogalska, 2013 
it as a memorial erected to fallen soldiers, but also stresses that they fell in some distant place. In his mind, the local Heldenhain is not truly "local," but is oriented on something general, far away, and not really connected to Žandov. By the time my fieldwork ended, the Horní Žandov heroes' grove was not yet renovated.

\section{Stained Glass Windows}

As early as 1919, in the Weimar Republic, the German Ministry of Science, Art and National Education (Ministerium für Wissenschaft, Kunst und Volksbildung) issued a letter advising municipalities not to erect new monuments but to use existing objects to commemorate fallen soldiers. One way to do that was to hang a plaque with a list of names in the local church. ${ }^{51}$ Commemorative church windows were a more elaborate way of commemorating the dead. They added the aura of medieval cathedrals to the memory of fallen soldiers and granted them a kind of apotheosis, linking contemporary fallen with medieval religion, as Stefan Goebel has observed. ${ }^{52}$ Such windows served to incorporate the memory of the recent and not very "heroic" war into the canon of earlier, more heroic wars. The medievalization of the memory of those who fell in the Great War was a common phenomenon in all German-speaking regions. ${ }^{53}$

An example of this can be seen in the Saint Michael Roman Catholic Church in Dolní Žandov (see Image 3). The biblical scene in one window of the church is dedicated to one particular fallen soldier by two families. The title of the stainedglass window is "Ehre sei Gott in der Höhe" [Glory to God in the Highest] which captions the depicted scene of an angel appearing to the shepherds on the night of Jesus' birth. The inscription below the scene is, however, not written in the classic German Fraktur font. It reads as follows: "Dem Andenken des Gefallenen Helden Josef Röll gewidm. v. Johann u. Margareta Röll und von Josef und Marie Krüss" [Dedicated to the Memory of the Fallen Hero Josef Röll from Johann and Margareta Röll and from Josef and Marie Krüss]. The scene is rendered in a medieval-ish, Gothic revival style. My hypothesis for the reason the particular scene was chosen is that the name of the soldier, Josef, recalls the nativity scene, where Saint Joseph was the father figure.

51 Document issued by the Ministry of Science, Art and National Education, August 20, 1919, 1, signature 161, collection Landratsamt Schievelbein, State Archive in Szczecin.

52 Goebel, The Great War and Medieval Memory, 57-58.

53 Ibid., 57-58. 


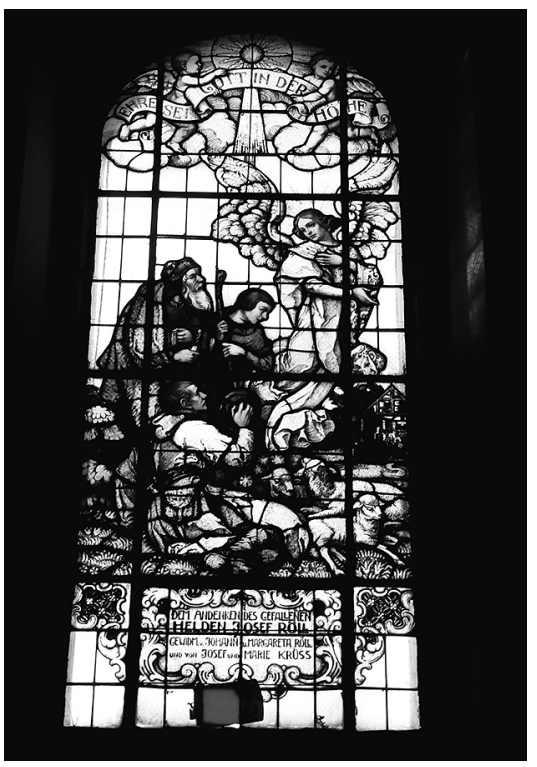

Image 3: Stained glass window in Saint Michael Roman Catholic Church, Dolní Žandov Author: Karolina Ćwiek-Rogalska, 2013

However, the scene has another meaning that employs religion in an attempt to give meaning to the experience of the recent war: the shepherds are not as they traditionally appear. Instead of three young men we see an old man, a boy and a man in the middle of his life. Together they represent the three stages of human life. The shepherds, as well as the architecture of the shed where the nativity takes place, remind the viewer of the local milieu. Žandov was a town where many inhabitants were farmers. The shed looks like the traditional half-timbered buildings that are still found in the neighborhood to this day. The angel appearing before the shepherds symbolizes a sudden call to do something unexpected, like the sudden mobilization for war. The life of a common citizen of Žandov who went to war, i.e., whose fate was influenced by something greater than himself, is thus ennobled. Even more: the fight for Heimat is here equated to the fight for heaven, or Himmelreich, to which the viewer's attention is drawn. God is present in the scene only as a beam of light in the sky. It is worth noting that the remainder of the Bible verse the window quotes is absent. The whole quotation is "Ehre sei Gott in der Höhe und 
Frieden auf Erden und den Menschen ein Wohlgefallen" [Glory to God in the Highest, and on earth peace, good will toward men] (Luke 2:14). ${ }^{54}$ Perhaps the window's donors decided to leave the rest of the quotation out because of its performative character. The phrase is well known and is recited during the Roman Catholic mass. When visitors to the church read the quotation, they are expected to add the rest themselves. Or maybe there is another interpretation: the direct invocation to peace was not highly regarded by the donors and they were trying to avoid mentioning it.

All the stained-glass windows in the Žandov church have been preserved to this day. This happened even though they all have German language inscriptions, like as the one described above, as an example of a local Kriegerdenkmal. Why were they not destroyed? I would argue that they do not have an overtly warlike or even specifically "German" character. By being placed in the sacred space of a church they became more universal. The stained-glass window described here is not only a memorial to the fallen Josef Röll, it is also a biblical scene and can be seen and interpreted on that level alone.

\section{Weeping and Sleeping Soldier Figures}

I would like to highlight one particular motif of Czechoslovak war memorials that is similar to one that can also be seen among the German Kriegerdenkmäler and the French monuments aux morts. This is the figure of a sleeping or weeping soldier. Examples of such figures from my fieldwork are found in the villages of Palič (see Image 4), Vysoká (see Image 5) and Milíkov (see Image 6). The soldier-figures are all contemporary to the World War I period in style, but they also show some links to medieval times that are different in each village. The soldier depicted in Palič is wearing the German Stahlhelm helmet and a uniform. He stands, holding a wreath. The wreath is most likely composed of oak leaves, because "the oak wreath...was clearly a symbol of nationalist ideals," as Karen E. Till states. ${ }^{55}$ Till draws upon George L. Mosse's observation that using the oak as a motif implied that "nature herself was to serve as a living memorial.... The oak, whose symbolic strength had been invoked during the Wars of Liberation, was considered the 'German tree.”"56

\footnotetext{
54 The English quotation is from the King James version of the Bible.

55 Till, "Staging the Past," 257.

56 Mosse, Fallen Soldiers, 87.
} 


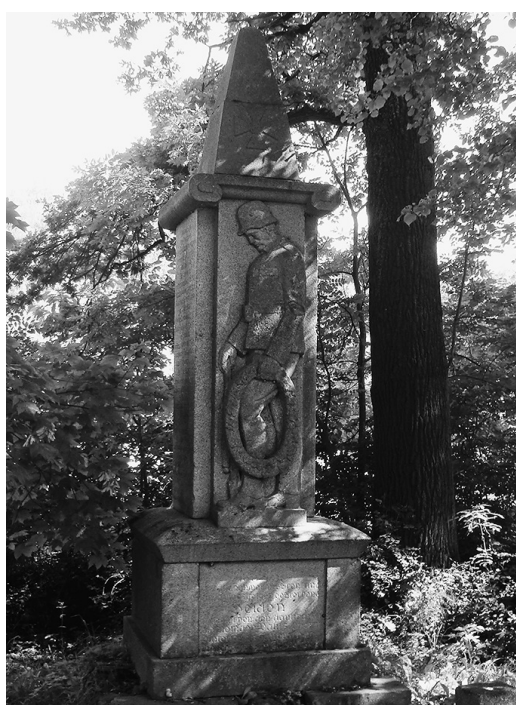

Image 4: War memorial, Palič

Author: Karolina Ćwiek-Rogalska, 2013

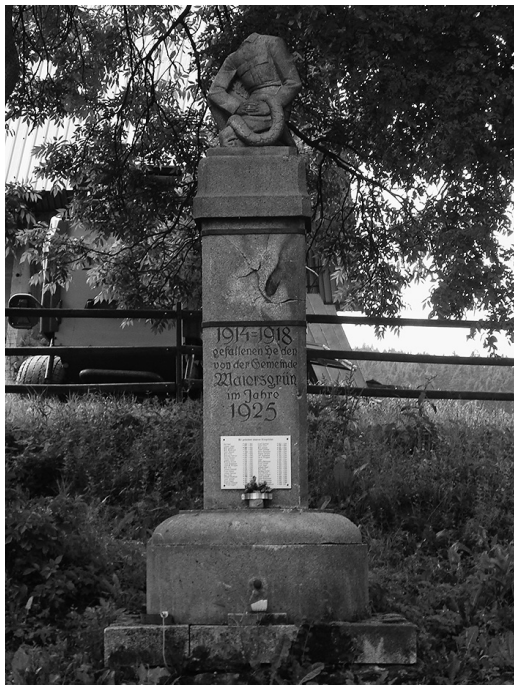

Image 5: War memorial, Vysoká

Author: Karolina Ćwiek-Rogalska, 2014 


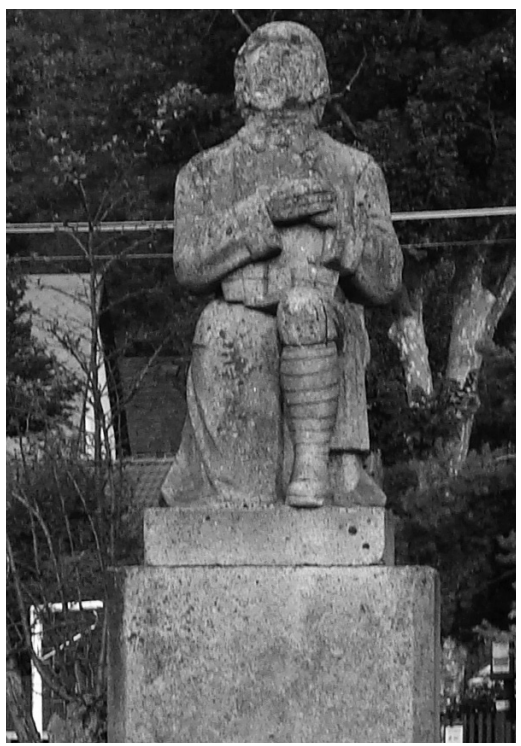

Image 6: War memorial, Milíkov

Author: Karolina Ćwiek-Rogalska, 2013

The soldier depicted in the memorial in Vysoká requires close inspection to be recognized as a contemporary World War I soldier. Having been damaged in 1945, he is missing his head. He is in uniform, kneeling, and holding an oak wreath, as does the soldier in Palič. The third memorial, in Milíkov, can easily be mistaken for a kneeling medieval knight instead of a World War I soldier. His face is unrecognizable and the viewer is unsure whether he is wearing a helmet or a medieval kind of haircut. His uniform coat is rather long and takes the form of a robe. The only visible hints that this is a soldier from the World War I era are a cartridge belt and the puttees he is wearing.

The defacement of the statues also adds an interesting sort of medieval quality to the memorials. Especially in the two latter cases, where the head or face is missing, the figures of the soldiers are even more knight-like than not. The stories that interviewees told me about them support this interpretation. As one of them said:

There was a soldier in Milíkov, he laid in front of the cemetery.... But there was no head. The head was destroyed.... Well, the soldier's been without a head for a long 
time. And there are some gardens in front of the cemetery. And some women were digging there and they found this head. ... It's a little bit damaged however. ${ }^{57}$

The defacement of the monuments made the soldiers more anonymous, more universal, and in a way, more open to different interpretations of what they were meant to symbolize.

Plaques with the names of fallen soldiers were originally added to all of these monuments. As the photographs reveal, not all the plaques survived. In Palič, which is a remote village, almost without permanent inhabitants who might have had reason to deface its memorial, the plaque is still there, although the names are barely readable. In Vysoká, it has been renovated, but in Milíkov there is no sign of it. Removing the plaque, which was the most meaningful part of the war memorial ${ }^{58}$ to the local German population, was a way to obliterate the memory of the dead of Milíkov.

\section{Conclusions}

As in the cases above, the fate of the German Great War memorials in the Czech borderlands after the expulsion of the German-speaking inhabitants and resettlement of the region by new settlers varied a lot. Some memorials were preserved; others were intentionally destroyed or simply left to be destroyed by time. Was there anything that had a decisive impact on which memorials were preserved and which were destroyed? It is tempting to suggest that there were some definite reasons behind the behavior of the new settlers, but that would be false. As can be seen in the cases from two small regions of the borderlands, the reaction to war memorials differed from village to village, which were separated by distances of only a few kilometers.

I can say, however, that the monuments with figures of soldiers were more endangered than the others. They shared a similar fate because they were recognizable signs of "German-ness." They were targeted because the figures were meant to embody the "German spirit" or because they personified the "enemy." Their destruction was a tool of revenge, and indeed, most of them were beheaded or lost limbs or other parts of their bodies. Most of the monuments

\footnotetext{
57 Field interview, Podlesí, taken on July 18, 2013. In the original Czech: “Tam byl voják v Milíkově, ležel před hřbitovem shozenej. ... Jenže tam nebyla hlava. Ta hlava byla uražená. ... No tak voják tam dlouho byl bez hlavy. No a tam jsou pod hřbitovem nějaké zahrady. A ženský ryly a našly tu hlavu. ... Je poškozená jako trochu."

58 Kessler, Pamèt'v kameni, 39.
} 
were also deprived of their plaques, the things that were most meaningful about them. Things that were more abstract and symbolic, like oak wreaths, were left in place, since they did not have an explicit meaning for the new inhabitants. Nevertheless, the fact that they were defaced or destroyed shows that they were seen as a part of a "dissonant" heritage, as I argued above.

Some monuments were recycled and parts of them were used in new commercial buildings, fences and houses. Some parts of them, considered neutral in their meaning, were re-used for decorative purposes. One example is the Dolní Žandov war memorial, which was completely dismantled. Nonetheless, the figure of a lion from the memorial was preserved and nowadays is a decoration in the yard of a summer house in Pístov, a village near Tachov. The places where the monuments stood were sometimes re-purposed, keeping their character as places that "meant something," even though the "something" was changed.

The aesthetic value of the memorials did not have a decisive impact on their preservation. As Zdeněk Hojda and Jiří Pokorný argue, people venerate a monument not because of its aesthetic value, but very often in spite of its lack of such value. ${ }^{59}$ We can, however, risk the hypothesis that some of the memorials were actually preserved because of their multiple meanings. Other connotations than that of the cult of the fallen soldier were coded into them. These meanings were decoded by new settlers as culturally and politically neutral, or as being close enough to the meanings of their own culture that a decision was made to save the monuments that conveyed them.

Memorials that bear some religious meaning, or that were recognized as referring to something more than just the memory of fallen German soldiers, have been preserved for the most part. It is interesting that the monuments that were erected near a church or in the vicinity of one were not destroyed. The dead soldiers that were commemorated on them were still known more as "local dead" than "fallen enemy soldiers" - even if they were relegated to some distant "memoryland" 60 - as were those mentioned by the interviewee from Horní Žandov, above.

\footnotetext{
${ }^{59}$ Hojda and Pokorný, Pomniky a zapomniky, 15.

${ }^{60}$ Sharon Macdonald, Memorylands: Heritage and Identity in Europe Today (London: Routledge, 2013).
} 